\title{
Impact of Industrially Affected Soil on Human: a Soil-human and Soil-plant-human Assessment
}

Yeasmin Nahar Jolly ( $\nabla$ jolly_tipu@yahoo.com )

Atomic Energy Centre https://orcid.org/0000-0002-7406-8951

\section{Sadman Sakib}

Jahangirnagar University

M. Ashemus Shahadat

Jahangirnagar University

Md. Refat Jahan Rakib

Noakhali Science and Technology University

Arafat Rahman

University of Dhaka: Dhaka University

Shirin Akter

Atomic Energy Centre

Jamiul Kabir

AECD: Atomic Energy Centre

Khan M. Mamun

AECD: Atomic Energy Centre

M. Safiur Rahman

AECD: Atomic Energy Centre

Bilkis Ara Begum

AECD: Atomic Energy Centre

\section{Rubina Rahman}

Jahangirnagar University

\section{Research Article}

Keywords: Metal translocation, soil, vegetables, multivariate statistical analysis, pollution degree, health risk

Posted Date: January 24th, 2022

DOI: https://doi.org/10.21203/rs.3.rs-1196414/v1

License: (1) This work is licensed under a Creative Commons Attribution 4.0 International License. 



\title{
Impact of industrially affected soil on human: A soil-human and soil-plant-human assessment
}

3

4

2

\author{
Yeasmin Nahar Jolly ${ }^{1^{*}}$, M. SadmanSakib ${ }^{2}$, M. Ashemus Shahadat ${ }^{2}$, M. Refat Jahan Rakib ${ }^{3}$, Arafat \\ Rahman ${ }^{4}$, Shirin Akter ${ }^{1}$, Jamiul Kabir ${ }^{1}$, Khan M. Mamun', M. Safiur Rahman', Bilkis Ara Begum ${ }^{1}$, \\ Rubina Rahman ${ }^{2}$ \\ ${ }^{1}$ Atmospheric and Environmental Chemistry Laboratory, Chemistry Division, Atomic Energy Centre, P.O. Box 164, \\ Dhaka 1000, Bangladesh \\ ${ }^{2}$ Department of Physics, Jahangirnagar University, Savar, Bangladesh. \\ ${ }^{3}$ Department of Fisheries and Marine Science, Noakhali Science and Technology University, Noakhali \\ ${ }^{4}$ Department of Soil, Water and Environment, University of Dhaka, Dhaka 1000, Bangladesh
}

\section{Abstract}

Present study was sketched to estimate the level of heavy metals $(\mathrm{Cr}, \mathrm{Fe}, \mathrm{Cu}, \mathrm{Zn}, \mathrm{As}$ and $\mathrm{Pb})$ in the industrially affected soil, their source apportionment, degree of pollution and estimation of probable health risk by direct soil exposure and via dietary intake of vegetables grown in the affected soil. Mean concentrations of $\mathrm{Cr}, \mathrm{Fe}, \mathrm{Cu}, \mathrm{Zn}, \mathrm{As}$ and $\mathrm{Pb}$ was found 61.27, 27274, 42.36, 9.77, 28.08 and 13.69 and $0.53,119.59,9.76,7.14,1.34$ and $2.69 \mathrm{mg} / \mathrm{kg}$ for affected soil and vegetable samples, respectively. The origin of $\mathrm{Fe}, \mathrm{Cu}, \mathrm{Zn}$ and $\mathrm{Pb}$ were found lithogenic, while $\mathrm{Cr}$ and $\mathrm{As}$ were anthropogenic. A moderate enrichment was noted by $\mathrm{Cr}, \mathrm{As}$, and $\mathrm{Pb}$ in the entire sampling site, indicating a progressive depletion of soil quality. Bioaccumulation factor (BCF) value for all the vegetables were recorded $\mathrm{BCF}<1$; however Metal pollution index (MPI) value stipulate a pretty high value in the vegetable samples. Health effect on account of direct exposure of contaminated soils manifested more hazardous than dietary intake of heavy metal contaminated vegetables and children were found more vulnerable receptors compare to adults. However, this study can be used as a reference towards similar types of study to evaluate heavy metal contaminated soil impact on the population of Bangladesh and other countries as well.

Keywords Metal translocation, soil, vegetables, multivariate statistical analysis, pollution degree, health risk

\section{${ }^{*}$ Corresponding author}

E-mail: jolly_tipu@yahoo.com 3 4

\section{Introduction}


The fundamental part of ecosystem is soil that supplies necessary nutrients to the living organisms. Soil receives different types of metals (heavy metal, toxic element, trace element) coming from various sources (anthropogenic and lithogenic), increasing their natural content, thus reducing the soil quality. However, as a reservoir, the soil itself is abundant of metals transported from biomass, atmosphere, and hydrosphere (Gbadamosi et al. 2018; Duan et al. 2020), but when it exceeded the safe/threshold limit may provoking risk to human and ecosystem. Contamination of soil by metals becomes a prime concern worldwide, as heavy metals are non-degradable and affect the human body adversely. Among the anthropogenic sources; mining, smelting, industrialisation, agrochemicals, urbanisation, domestic wastes, and transportation are significant contributor, while for lithogenic sources; weathering and erosion of bedrocks and ore deposit are dominating (Cai et al. 2012). However, the increasing concentration of heavy metals in soil predominantly affects the food chain and consumption of contaminated food makes the population vulnerable to health hazards (non-carcinogenic and carcinogenic) (Khan et al. 2014; Akter et al. 2019; Kumar et al. 2020).

Heavy metal (HM) contaminated soil may pose potential risks and hazards to humans by direct ingestion or contact with contaminated soil or inhalation of contaminated soil dust and via food chain. Thus, health risks arise from soil can be estimated by calculating various soil pollution indices of HMs, their soil-to-plant transfer factors, direct exposure level to human and their levels in edible food crops as well as health risk due to consumption of contaminated food crops. A numerous studies have been conducted all over the world and so as Bangladesh, to estimate health hazards by heavy metal contaminated soil (Chabukdhara et al. 2013; Jin et al. 2019; Gupta et al. 2021; Rahman et al. 2021) and food contamination (Jolly et al. 2013a; Hu et al. 2017; Islam et al. 2017; Jolly et al. 2019; Quispe et al. 2021; Rakib et al. 2021a) individually but in this study health effect due to heavy metal contaminated soil and vegetables grown on the same industrially affected soil have been computed, moreover to ascertain the pollution degree, soil from a non-contaminated area having the similar soil texture were also analyzed to get a baseline soil data of that particular area and hence the novelty of the study.

Ashulia, a neighboring community of Dhaka district (the capital of Bangladesh), which is a suburban area, and Savar is a nearby area having the same soil texture was targeted as the sampling sites. A vast number of paddy fields and agricultural lands are located in the study area. Ashulia Lake and two major theme parks of Bangladesh, namely "Fantasy Kingdom" and "Nandan Park", make it very popular to the tourist. A huge number of local and foreign tourists including children visited this area frequently. However, in the recent years, rapid urbanisation, establishment of garments factories, bricks fields and other factories deteriorated its beauty and reduced the farmlands. Frequent dumping of untreated solid and liquid wastes from the factories and brickfields to the agricultural land nearby makes them assailable due to the risk of metal accumulation into crops, vegetables and ultimately to human body. Thus this area has been chosen as a model to study the adverse effect of industrial establishments on agricultural land as well as on food crops and ultimately on human health. In this context, the present study was aimed to measure $\mathrm{HMs}(\mathrm{Fe}, \mathrm{Cr}, \mathrm{Cu}, \mathrm{Zn}, \mathrm{As}, \mathrm{Pb})$ in soil affected by the industrial wastes and vegetables grown on affected soil, determination of pollution degree by estimating various indices and multivariate statistical analysis was employed to find out the possible pollution sources as well. Health risk owing to soil-human and soil- plant-human route was assessed and a comparison was made to ascertain which path is more vulnerable. Translocation of heavy metals from soil to edible parts of vegetables was also done to find out the metal extraction capability of the plants from a phytoremediation point of view.

\section{Material and Methods}

\subsection{The study site and sample collection}

Ten industrially affected soil samples designated as IS1 $\left(23^{\circ} 54^{\prime} 19.1^{\prime \prime} \mathrm{N} 90^{\circ} 17^{\prime} 35.0^{\prime \prime} \mathrm{E}\right)$, IS2 $\left(23^{\circ} 54^{\prime} 19.9^{\prime \prime} \mathrm{N}\right.$ $\left.90^{\circ} 17^{\prime} 36.3^{\prime \prime E}\right), \quad$ IS3 $\quad\left(23^{\circ} 54^{\prime} 16.3^{\prime \prime} \mathrm{N} \quad 90^{\circ} 17^{\prime} 38.2^{\prime \prime} \mathrm{E}\right), \quad$ IS4 $\quad\left(23^{\circ} 54^{\prime} 15.9^{\prime \prime} \mathrm{N} \quad 90^{\circ} 17^{\prime} 38.4^{\prime \prime} \mathrm{E}\right), \quad$ IS5 $\quad\left(23^{\circ} 54^{\prime} 16.1^{\prime \prime} \mathrm{N}\right.$ $\left.90^{\circ} 17^{\prime} 39.8^{\prime \prime} \mathrm{E}\right), \quad$ IS6 $\quad\left(23^{\circ} 54^{\prime} 12.4^{\prime \prime} \mathrm{N} \quad 90^{\circ} 17^{\prime} 37.3^{\prime \prime} \mathrm{E}\right), \quad$ IS7 $\quad\left(23^{\circ} 54^{\prime} 12.9^{\prime \prime} \mathrm{N} \quad 90^{\circ} 17^{\prime} 18.0^{\prime \prime} \mathrm{E}\right), \quad$ IS $8{ }^{\circ}\left(23^{\circ} 54^{\prime} 35.6^{\prime \prime} \mathrm{N}\right.$ $\left.90^{\circ} 17^{\prime} 31.8^{\prime \prime E}\right)$, IS9 $\left(23^{\circ} 54^{\prime} 42.6^{\prime \prime} \mathrm{N} 90^{\circ} 17^{\prime} 31.1^{\prime \prime} \mathrm{E}\right)$ and IS10 $\left(23^{\circ} 54^{\prime} 47.0^{\prime \prime} \mathrm{N} 90^{\circ} 17^{\prime} 30.3^{\prime \prime} \mathrm{E}\right)$ were collected from the upper surface region (5-15 cm depth) of agricultural land of Ashulia, Dhaka (Fig. 1). A large number of industrial establishments comprised of local and foreign industries like fabric printing and dyeing, food processing, textiles, electric cables, pharmaceutical, chemical, etc., are located near the sampling station and wastes from those industries

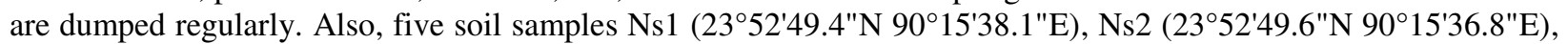

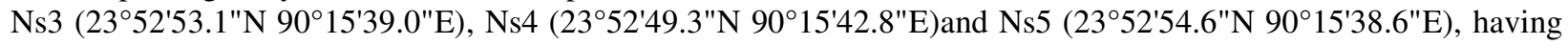
the similar soil texture, considered as control soil and used as background soil were collected from Jahangirnagar University area, Savar (Fig. 1), where anthropogenic input was completely absent. To evaluate contaminated soil 
impact on human health via food consumption, 15 verities of vegetables namely Spinach, Cabbage, Red Amaranth, Coriander leaf, Tomato, Brinjal, Bean, Pumpkin, Bottle gourd, Papaya, Green banana, Cauliflower, Carrot, Radish, Potato were collected that have been grown in and around the industrially affected soil sampling sites (Fig. 1).

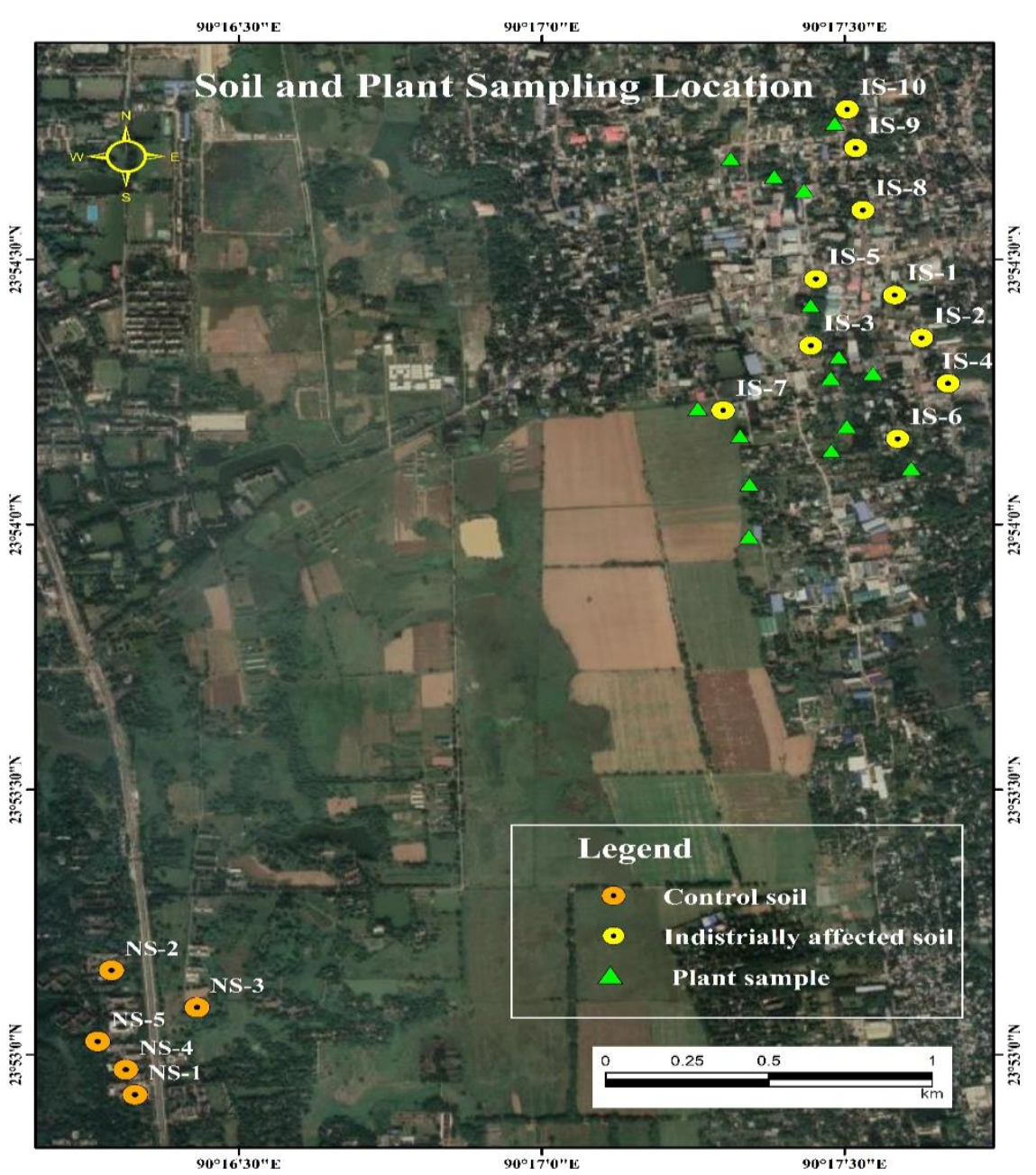

Fig.1 Map of soil (control and affected) and vegetable sampling locations

\subsection{Sample preparation}

Each soil sample was sieved, dried to remove moisture and finally ground to fine powder. Vegetable samples were initially cleaned with tap water and rinsed with deionized water to remove any trace of ion, cut into small pieces, dried to remove moisture and the dried mass was ground to fine powder. Finally, $0.1 \mathrm{gm}$ of each soil and vegetable sample in triplicate were pressed into a pellet of $0.7 \mathrm{~cm}$ diameter and $1 \mathrm{~mm}$ thickness using a pellet maker. The whole process is outlined following Jolly et al. (2013b) and Akter et al. (2019).

\subsection{Elemental analysis of soil and vegetable sample using EDXRF}


Soil and vegetable samples were analysed for heavy metals $(\mathrm{Cr}, \mathrm{Fe}, \mathrm{Cu}, \mathrm{Zn}, \mathrm{As}, \mathrm{Pb})$ using Energy Dispersive X-ray Fluorescence (EDXRF) system. It's a non-destructive, multielemental, nuclear analytical technique, well suited for solid sample (soil, sediment, vegetables, foodstuff etc.) analysis. Many research works have been conducted with this technique for heavy/trace metal determination in environmental and food samples (Jolly et al. 2013a; Islam et al. 2014; Jolly et al. 2017; Islam et al. 2017; Nabulo et al. 2011; Hossain et al. 2020; Sekara et al. 2005) as sample preparation is very simple, no chemical treatment or digestion is required, thus reducing system loss(Gallardo et al. 2016), moreover accuracy and precision of the obtained data are excellent. However, the quality assurance and quality control $(\mathrm{QA} / \mathrm{QC})$ of the soil and vegetable data were addressed by using certified reference materials (Montana-1/2710a for soil and Orchard leaf/NIST 15710 for vegetable samples), where recovery percentage of heavy metals (HMs) in the samples ranged from $93 \%$ to $106 \%$, and the relative error for standard reference materials was around 5\%. The entire process was described elsewhere (Jolly et al. 2013b; Akter et al. 2019).

\subsection{Determination of HMs contamination status through indices for soil}

Soil pollution degree was measured by calculating Enrichment factor (EF), Geo-accumulation index (Igeo), Contamination factor (CF), and Pollution load index (PLI) as per Rakib et al. (2021b). whereas plant contamination levels were calculated by using Bioaccumulation Factor (BCFs) and Metal pollution index (MPI) as per Jolly et al. (2013a) and Hossain et al. (2020). The equation used to calculate the contamination indices are:

$$
\mathrm{EF}=\frac{\left(\frac{\mathrm{Me}}{\mathrm{Fe}}\right)_{\text {sample }}}{\left(\frac{\mathrm{Me}}{\mathrm{Fe}}\right)_{\text {background }}}
$$

where, $\mathrm{EF}$ refers to enrichment factor, $(\mathrm{Me} / \mathrm{Fe})_{\text {sample }}$ refers to the ratio of concentration between the studied metal and $\mathrm{Fe}$ in the sample of interest; $(\mathrm{Me} / \mathrm{Fe}$ ) background is the natural background value (control soil in this case) of measured metal to Fe ratio(Birch and Olmos 2008). However, EF lies in the classes as $\mathrm{EF}=1$, crustal materials or natural weathering processes, $\mathrm{EF}<2$ (Deficiency to minimal enrichment), $2 \leq \mathrm{EF}<5$ (Moderate enrichment), $5 \leq \mathrm{EF}<20$ (Significant enrichment), $20 \leq \mathrm{EF}<40$ (Very high enrichment) and $\mathrm{EF} \geq 40$ (Extremely high enrichment).

$$
\mathrm{I}_{\mathrm{geo}}=\log 2 \times \frac{\mathrm{C}_{\mathrm{n}}}{1.5 \mathrm{Bn}}
$$

where, $I_{\text {geo }}$ is the geo-accumulation index; $C_{n}$ is the individual heavy metal concentration; $B_{n}$ is the geochemical background value (Control soil value) and factor 1.5 is introduced to include possible variations of the background values due to the lithogenic effect (Muller 1969). I Igeo value can be categorised (Martin and Meybeck 1979) as Igeo $\leq 0$ (unpolluted), $I_{\text {geo }}=0-1$ (unpolluted to moderately polluted), $I_{g e o}=1-2$ (moderately polluted), $I_{g e o}=2-3$ (moderately to strongly polluted), $\mathrm{I}_{\mathrm{geo}}=3-4$ (strongly polluted), $\mathrm{I}_{\mathrm{geo}}=4-5$ (strongly to extremely polluted) and $\mathrm{I}_{\mathrm{geo}}=5-6$ (extremely polluted).

$$
\mathrm{CF}=\frac{\mathrm{C}_{\mathrm{m} \text { sample }}}{\mathrm{C}_{\mathrm{m}} \text { background }}
$$

where, $\mathrm{CF}$ is the contamination factor; $\mathrm{C}_{\mathrm{m} \text { sample }}$ is the concentration of a given metal; $\mathrm{C}_{\mathrm{m}}$ background is the background value of the metal (control soil) (Hakanson 1980). CF is categorised (Martin and Meybeck 1979) as CF $<1$ (low contamination), $1 \leq \mathrm{CF}<3$ (moderate contamination), $3 \leq \mathrm{CF}<6$ (considerable contamination) and $\mathrm{CF} \geq 6$ (very high contamination).

$$
\mathrm{PLI}=\left(\mathrm{CF}_{1} \times \mathrm{CF}_{2} \times \mathrm{CF}_{3} \times \cdots \cdot \mathrm{CF}_{\mathrm{n}}\right)^{1 / \mathrm{n}}
$$

where, PLI is the pollution load index; $\mathrm{n}$ is the number of metals to be analysed and PLI is categorised by Tomilson et al. (1980) as PLI < 1 denotes perfection; PLI=1 denotes baseline levels of pollutants; PLI>1 indicate deterioration of site quality.

\subsection{Apportionment of possible sources of soil pollution}

Multivariate statistical methods are usually applied to evaluate the complex eco-toxicological processes regarding the relationship and interdependency among the variables and their relative weights (Bartolomeo et al. 2004). In this study, a popular multivariate statistical method, principal component analysis (PCA) was employed to verify the significant relationships between heavy metals in the soil samples (Jolliffe and Cadima 2016) and cluster analysis (CA) was done to characterize notable variability among sites, using Euclidean distance for dissimilarity matrix and Ward's method as the linkage method (Rahman et al. 2021).Ward's method defines the proximity between two clusters as the increase in the squared error.

The data obtained from this study were analyzed statistically using SPSS version 25.0 software (IBM SPSS Inc., USA), graphs were displayed with using Microsoft Excel 2019, and Box-whisker plots were plotted with OriginPro 
software version 9.0. The analysis of variance (ANOVA) tests at a significance level of $95 \%$ were used to evaluate the impact of different variables on the contamination in the study area. PCA and CA were performed using SPSS.

\subsection{Determination of HMs contamination status through indices for vegetables}

Vegetable contamination levels were calculated by using Bioaccumulation Factor (BCFs) and Metal pollution index (MPI) as per Hossain et al. (2020) and Jolly et al. (2013a).

\subsubsection{Bioaccumulation Factor (BCFs)}

The equation (5) is used to calculate bioaccumulation factors (BCFs) of the heavy metals from soil to plant,

$$
B C F S=\frac{C_{v e g}}{C_{\text {soil }}}
$$

where, $\mathrm{C}_{\mathrm{veg}}$ is the concentration of heavy metal in the vegetable $(\mathrm{mg} / \mathrm{kg}, \mathrm{dw})$, and $\mathrm{C}_{\text {soil }}$ is the concentration of heavy metal in the soil (mg/kg, dw) (Guo et al. 2019). It is notable that the translocation abilities of the heavy metals from soil to the edible parts of the vegetables can be evaluated by this factor and BCF> 1 reveals the plant can effectively translocate heavy metals from soil to the edible portion of the vegetables (Hossain et al. 2020).

\subsubsection{Metal Pollution Index (MPI)}

This index was obtained by calculating the geometrical mean of concentration of all the metals in the analysed vegetable samples (Ureso et al. 1997; Jolly et al. 2013b).

$$
\operatorname{MPI}(m g / k g)=\sqrt[n]{C f 1 \times C f 2 \times \ldots \ldots C f n)}
$$

where, $\mathrm{Cf}_{\mathrm{n}}$ is the concentration of $\mathrm{n}$ number of metals in the sample.

\subsection{Human exposure and health risk assessment indices}

Heavy metal contaminated soil can affect human health in two pathways: 1) soil to human via direct soil (dust) exposure; 2) soil to food to human via consumption of vegetables.

\subsubsection{Soil to human health risk assessment}

Ingestion of particles $\left(\mathrm{ADD}_{\mathrm{ing}}\right)$; inhalation $\left(\mathrm{ADD}_{\mathrm{inh}}\right)$; dermal absorption of metals via skin ( $\mathrm{ADD}$ Dermal) (Ihedioha et al. 2017) are the three main routes for human soil direct exposure and are evaluated by the equation suggested by US EPA $(1989,2001)$.Thus, the non-carcinogenic risk HQ for heavy metal contaminated soil was measured by using the Eq. (7):

$$
\text { Hazard Quotient }(\mathrm{HQ})=\frac{\mathrm{ADD}}{\mathrm{RfD}}
$$

where, $\mathrm{ADD}$ refers the dose due to the exposure of heavy metals $\left(\mathrm{ADD}_{\text {inges }}+\mathrm{ADD}_{\text {inha }}+\mathrm{ADD}_{\text {derm }}\right)$ and $\mathrm{RfD}$ refers the heavy metal $(\mathrm{HM})$ oral reference dose. RfD for ingestion: $\mathrm{Fe}=7.00 \mathrm{E}-01, \mathrm{Cr}=3.00 \mathrm{E}-03, \mathrm{Cu}=0.04, \mathrm{Zn}=0.3, \mathrm{As}=$ 3.00E-04and $\mathrm{Pb}=0.0035$; for inhalation: $\mathrm{Cr}=2.86 \mathrm{E}-05, \mathrm{Cu}=0.0402, \mathrm{Zn}=0.3, \mathrm{As}=3.01 \mathrm{E}-04 \mathrm{and} \mathrm{Pb}=0.00352 ; \mathrm{for}$ dermal contact: $\mathrm{Cr}=6.00 \mathrm{E}-05, \mathrm{Cu}=0.012, \mathrm{Zn}=0.06, \mathrm{As}=1.23 \mathrm{E}-04$ and $\mathrm{Pb}=0.000525$ (Ihedioha et al. 2017;Onyele and Anyanwu 2018; Sun and Chen 2018; Rahman et al. 2019; Rinklebe et al. 2019).

The non-carcinogenic effect for n number of heavy metals, on population, is the sum of all HQ's, represented as Hazard Index (HI), (USEPA 1989). Hence, it is mention-worthy that HI/HQ<1 denotes highly unlikely significant toxic interaction and HI/HQ>1 denotes potential non-cancer health effect (Enuneku et al. 2018). On the other hand, carcinogens risks (CR) are estimated by the Eq. (8):

$$
\mathrm{CR}=L A A d \times S F
$$

where, $\mathrm{LAAD}=(\mathrm{LAAD}$ ing, $+\mathrm{LAAD}$ inh $+\mathrm{LAAD}$ derm $)$ is the lifetime average daily dose expressed as a weighted average for each exposure path, SF is the slope factor for a particular carcinogenic element (US EPA 1996, 2001; Rahman et al. 2019) and $\mathrm{SF}$ value for ingestion, $\mathrm{As}=1.5, \mathrm{~Pb}=0.009$; for inhalation, $\mathrm{As}=1.51+\mathrm{E} 01, \mathrm{Cr}=4.20 \mathrm{E}+01$; for dermal, As=3.66E+00, $\mathrm{Cr}=2.00 \mathrm{E}+01$ (Rahman et al. 2019). Notably, the value within the range of $1.0 \mathrm{E}-04$ and 1.0E-06 are considered as an acceptable level (USEPA 1989) but when the value exceeds $1.0 \mathrm{E}-04$ then, it is considered as a lifetime carcinogenic risk to the person exposed. Detailed of the indices (non-carcinogenic and carcinogenic) are computed in Table 1. Li et al. (2017) and Orosun (2021) suggested seven categories of risk due to exposure of carcinogenic metal: $<1 \mathrm{E}-06$ (level I, extremely low risk); 1E-06 to 1E-05(level II, low risk); 1E-05 to 
5E-05 (level III, low-medium risk); 5E-05 to 1E-04 (level IV, medium risk); 1E-04 to 5E-04 (level V, medium to high risk); 5E-04 to 1E-03 (level VI, high risk); >1E-03 (level VII, extremely high risk).

\subsubsection{Soil to vegetable to human health risk assessment}

Estimated Daily Intake (EDI) of metals, Target Hazard Quotient (THQ), Hazard Index (HI), Cancer Risk (CR) and Total Cancer risk (TCR) are the indices addressed to estimate probabilistic risk due to consumption of vegetables grown in contaminated soil and detailed of the indices are computed in Table 2.

\section{$3 \quad$ Results and discussion}

\subsection{Heavy metal contents in soil samples}

Concentration of heavy metals $(\mathrm{Fe}, \mathrm{Cr}, \mathrm{Cu}, \mathrm{Zn}, \mathrm{As}, \mathrm{Pb})$ in the industrially affected soil along with control soil is presented in Table 3. The ranges of the heavy metal in the affected soil are 68.19-51.18, 34900-21840, 51.78-32.24, 57.94-44.88, 37.34-18.19 and $18.53-9.03 \mathrm{mg} / \mathrm{kg}$ for $\mathrm{Cr}, \mathrm{Fe}, \mathrm{Cu}, \mathrm{Zn}, \mathrm{As}$ and $\mathrm{Pb}$ respectively. The mean value of $\mathrm{Cr}$, $\mathrm{Fe}, \mathrm{Cu}, \mathrm{Zn}, \mathrm{As}$ and $\mathrm{Pb}$ in control soils are 13.45, 21570, 32.43, 35.33, 6.03, $5.61 \mathrm{mg} / \mathrm{kg}$ respectively (Table 3). Compared to control soil, affected soil ascertained a higher value (Table 3), however, the mean value of industrially affected soil can be ranked as $\mathrm{Fe}>\mathrm{Cr}>\mathrm{Zn}>\mathrm{Cu}>\mathrm{As}>\mathrm{Pb}$. According to "World soil average" reported by KabitaPendias (2011), the value of $\mathrm{Cr}, \mathrm{Zn}, \mathrm{Cu}, \mathrm{As}$ and $\mathrm{Pb}$ are 59.5, 70.0, 38.9, 6.83 and $27.0 \mathrm{mg} / \mathrm{kg}$, respectively and hence the measured value is higher except for $\mathrm{Zn}$ and $\mathrm{Pb}$ (Table 3). Jiang et al. (2014) and Toth et al. (2016) believed that the soil of old and more industrialized areas are comparatively high in elemental concentration. However, Antoniadisa et al. (2019) reported mean concentration of $\mathrm{Fe}, \mathrm{Cr}, \mathrm{Cu}, \mathrm{Zn}, \mathrm{As}, \mathrm{Pb}$ as 31488, 438.29, 39.78, 69.23, $100.33,2.45 \mathrm{mg} / \mathrm{kg}$, respectively in soil samples of an industrial area of Volos, Greece. Meanwhile, Rahman et al. (2021) reported mean concentrations of $\mathrm{Fe}, \mathrm{Cu}, \mathrm{Zn}$, and $\mathrm{Pb}$ were $21163,40.2,77.0$ and $19.5 \mathrm{mg} / \mathrm{kg}$ respectively, in the topsoil samples collected from schools of different locations in Dhaka city, Bangladesh. Furthermore, Jolly et al. (2013b) also reported mean concentration of $\mathrm{Fe}, \mathrm{Cr}, \mathrm{Cu}, \mathrm{Zn}, \mathrm{As}$ and $\mathrm{Pb}$ were 34500, 58, 53, 98, 41 and $15 \mathrm{mg} / \mathrm{kg}$, respectively, in the surface soil of Ishwardi, Pabna, Bangladesh, which was higher than the present study except Cr. Nevertheless Gupta et al. (2021) observed concentration of $\mathrm{Zn}, \mathrm{Pb}, \mathrm{Cu}$ and $\mathrm{Co}$ as 44.43, 14.62, 14.66 and 8.96 $\mathrm{mg} / \mathrm{kg}$ in the agriculture soil sample of North India, which are almost consistent with the present findings.

\subsection{Evaluation of pollution level in the studied soil}

Environmental ecological risk by the $\mathrm{HMs}(\mathrm{Cr}, \mathrm{Fe}, \mathrm{Cu}, \mathrm{Zn}, \mathrm{As}, \mathrm{Pb})$ were assessed by calculating single indices like enrichment factor $(\mathrm{EF})$, geo-accumulation index $\left(\mathrm{I}_{\mathrm{geo}}\right)$, contamination factor $(\mathrm{CF})$ and integrated index PLI. The estimated values for EF, $\mathrm{Ige}_{\mathrm{ge}} \mathrm{O}$ and $\mathrm{CF}$ are computed in Table 4.Measured EF value ranges from 2.80-4.754, 0.8231.491, 0.795-1.446, 1.646-4.957, 0.995-3.262 for $\mathrm{Cr}, \mathrm{Cu}, \mathrm{Zn}, \mathrm{As}$ and $\mathrm{Pb}$ among the sites, respectively (Table 4). According to Mohammad et al. (2015), when $\mathrm{EF}<1.5$, the elements are most likely earth's cluster origin, resulting from natural processes. In this study, Fe showed enrichment factor 1 for all the sites, indicating cluster metal, coming from weathering practice (Kormoker et al. 2019). $\mathrm{Cr}$ and As were found to show moderate enrichment $(2 \leq \mathrm{EF}<5)$ for all the sites, indicating anthropogenic impact (Birch and Olmos 2008), while Pb showed miscellaneous enrichment values (Table 4) among the sites of the study area, indicating both cluster and anthropogenic origin. Furthermore, $\mathrm{Cu}$ and $\mathrm{Zn}$ showed enrichment $<2$ for all sites, indicating deficiency to minimal enrichment and of geological origin. In a literature Zhang et al. (2016) reported, ranges of EF values were 1.10 - 10.95, 4.45 -18.95, $0.71-2.77,0.76-1.67,0.73-2.28,0.55-2.09$ and $0.80-2.09$ for $\mathrm{As}, \mathrm{Cd}, \mathrm{Cr}, \mathrm{Cu}, \mathrm{Ni}, \mathrm{Pb}$ and $\mathrm{Zn}$ respectively in the soils along a wetland-forming chronosequence in the Yellow River Delta of China. Rahman et al. (2021) also reported the average $\mathrm{EF}$ values of $\mathrm{Cu}, \mathrm{Zn}, \mathrm{As}, \mathrm{Pb}$ were 1.96, 1.29, 2.98, 1.23 respectively, in soils of the Dhaka city schools, Bangladesh.

The assessment of heavy metal contamination in soil based on the geochemical background of the metal can be calculated by evaluating $I_{\text {geo }}$ value (Weissmannova et al. 2019). Present study calculated $\mathrm{I}_{\text {geo }}$ for $\mathrm{Fe}, \mathrm{Cr}, \mathrm{Cu}, \mathrm{Zn}, \mathrm{As}$ and $\mathrm{Pb}$, and it was found to vary from element to element. The result revealed $\mathrm{I}_{\mathrm{geo}}=0-1$, for Fe for the sites IS6 and IS10 indicating unpolluted to moderately polluted by $\mathrm{Fe}$, but in all other sites, $\mathrm{I}_{\text {geo }}<0$ for $\mathrm{Fe}$ (Table 4), indicating minimal anthropogenic effects and recommended unpolluted by $\mathrm{Fe}$. In case of $\mathrm{Cu}$ and $\mathrm{Zn}, \mathrm{I}_{\mathrm{geo}}=0-1$ was found in the site IS6, IS7, IS10 and IS6, IS8, IS9, respectively, indicating unpolluted to moderately polluted status by the elements. At the same time, I Igeo $_{1}<0$ was measured in the sites IS1, IS2,IS3, IS4, IS5, IS8, IS9 and IS1, IS2, IS3, IS4, 
IS5, IS7, IS10, for $\mathrm{Cu}$ and $\mathrm{Zn}$ respectively, stipulating no pollution. In contrast, $\mathrm{Cr}$, As and $\mathrm{Pb}$ showed $\mathrm{I}_{\text {geo }}=0-1$ for all the soil samples, recommended unpolluted to moderately polluted by $\mathrm{Cr}$, As and $\mathrm{Pb}$. In a previous study $\mathrm{I}_{\mathrm{geo}}$ value for different soil samples of Dhaka city of Bangladesh was found in the range of -0.41 to $0.68,0.77$ to 1.68 , 0.47 to $1.14,1.52$ to $2.02,-0.64$ to $0.75,2.91$ to $4.13,-0.03$ to $0.85,-1.37$ to $0.27,-0.33$ to $1.16,-4.03$ to 0.08 , and 1.93 to 0.90 for $\mathrm{Fe}, \mathrm{Cu}, \mathrm{Zn}, \mathrm{As}, \mathrm{Pb}, \mathrm{Ti}, \mathrm{Rb}, \mathrm{Sr}, \mathrm{Zr}, \mathrm{K}$ and $\mathrm{Ca}$ respectively (Rahman et al. 2021), which are almost similar to the present findings. However, Negahban et al. (2021) reported an Igeo range of 1.20-0.57, 1.32-0.98, $2.97-0.88$ and $1.26-0.58$ for $\mathrm{Cu}, \mathrm{Zn}, \mathrm{Pb}$, and $\mathrm{Cd}$, respectively in soils of a large alluvial fan located in Neyriz, Iran, which was higher than the present study.

The contamination factor (CF) of the studied HMs are summarized in Table 4, which revealed all the sites are considerably contaminated by $\mathrm{Cr}$ (3.805-5.070); considerable to very highly contaminated by As (3.017-6.192), moderately contaminated by $\mathrm{Fe}(1.060-1.618), \mathrm{Cu}(0.994-1.597), \mathrm{Zn}(1.270-1.640)$ and $\mathrm{Pb}(1.610-3.303)$ but somehow in some sites (IS2, IS4, IS7) $\mathrm{Pb}$ showed $\mathrm{CF}$ value $3 \leq \mathrm{CF}<6$ and hence appraising considerable contamination. Prosad et al. (2021) also estimated considerable contamination by $\mathrm{Pb}$, low- moderate contamination by $\mathrm{Ni}$ and $\mathrm{As}$, and low-moderate-considerable contamination by $\mathrm{Cu}$ and $\mathrm{Pb}$ in Daulatpur soil of Kushtia district, Bangladesh. However, Zabir et al. (2016) reported a higher level of $\mathrm{CF}$ value (CF>5) for $\mathrm{Pb}, \mathrm{Rb}, \mathrm{Mg}$ and $\mathrm{Zn}$ in soil samples adjacent to Bhaluka Industrial Area, Mymensingh, Bangladesh.

Pollution load index (PLI) was calculated to assess the integrated index of pollution by heavy metals in the contaminated soil, which is depicted in Fig. 2. PLI values were observed in the decreasing order of IS6 (2.326) $>\operatorname{IS} 8(2.307)>\operatorname{IS} 4(2.291)>I S 10(2.287)>I S 7(2.285)>I S 5(2.265)>I S 9(2.231)>I S 2(2.130)>I S 1(2.009)>I S 3$

(1.927) and found PLI $>1$ for all the sites indicating high load of HM in the sampling site and progressive deterioration. Prosad et al. (2021) reported a low-level PLI value (PLI $<1)$ for the heavy metals $\mathrm{Cr}, \mathrm{Cd}, \mathrm{Cu}, \mathrm{Ni}, \mathrm{As}$ and $\mathrm{Pb}$ in the soil samples of different area of Kushtia and Jinaidah district of Bangladesh.

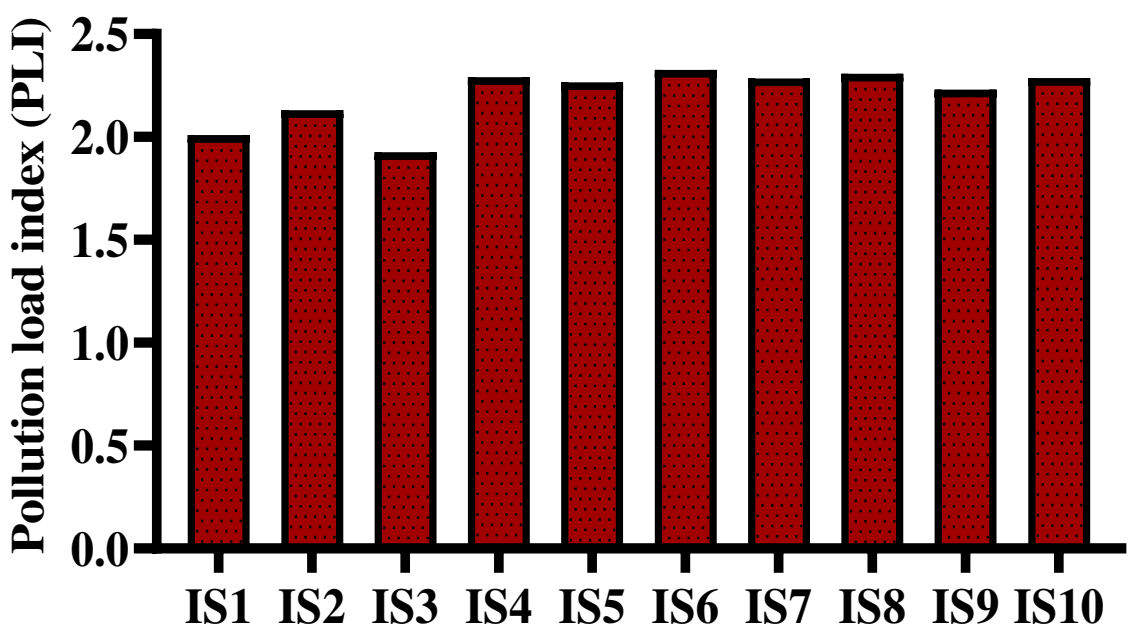

\section{Sampling sites}

Fig. 2 Pollution load index of the sampling sites of the study area

\subsection{Apportionment of possible sources of soil pollution}

Cluster analysis is designed for the better identification of a distinguishable group of items at the sampling site against the detected parameters with respect to notable variability (Rakib et al. 2021b). The extent of contamination can be depicted by cluster formation as identical sited are clustered in one group and unalike sites are clustered in another group (Rahman et al. 2021). Two-way hierarchical cluster heatmap and dendrogram, developed by the Ward linkage method with Euclidean distance, were used in this study and the obtained results are presented in Fig. 3 . 
In the vertical portion, the dendrogram provided two clusters: $\mathrm{As}, \mathrm{Zn}, \mathrm{Fe} \mathrm{Cu}$ and $\mathrm{Cr}$ had been confined in cluster 1, and $\mathrm{Pb}$ was displayed in cluster 2, which mostly confirmed in line with the PCA result. Such findings strongly confirmed a similar origin of the selected metal elements. In contrast, the horizontal dendrogram rendered three clusters, where IS1, IS9 and IS3 imparted to cluster 1; IS10, IS7, IS6 and IS5 imparted cluster 2 , IS2, IS4 and IS8 imparted cluster 3 .

The principal component analysis (PCA) was conducted to determine the correlation and retrospective sources of the tested elements (Hossain et al. 2021; Rakib et al. 2021b). The corresponded PCA was executed following rotated component plot concerning the loadings depicted in Fig. 4. The PCA plot was based on the eigenvalues greater than 1, and the relations were apparent. In Fig. 4, all the metal contents moved toward the positive direction of the axis PCA1, which revealed that they were associated, each other (Wei et al. 2018). The executed PCA resulted in two corresponding factors; PC1 contributed $41.5 \%$, while PC2 rendered $21.1 \%$ of the total variance. $\mathrm{Cr}$ was at 0.8 substantial positive loads, indicating an anthropogenic source of contaminants, and $\mathrm{Zn}, \mathrm{Pb}$ and As were also positive, but below 0.5 indicated moderate loadings. In contrast, $\mathrm{Fe}$ and $\mathrm{Cu}$ were found negative loadings where $\mathrm{Cu}$ value indicate strong loadings (-0.7) reflecting a lithogenic sources.

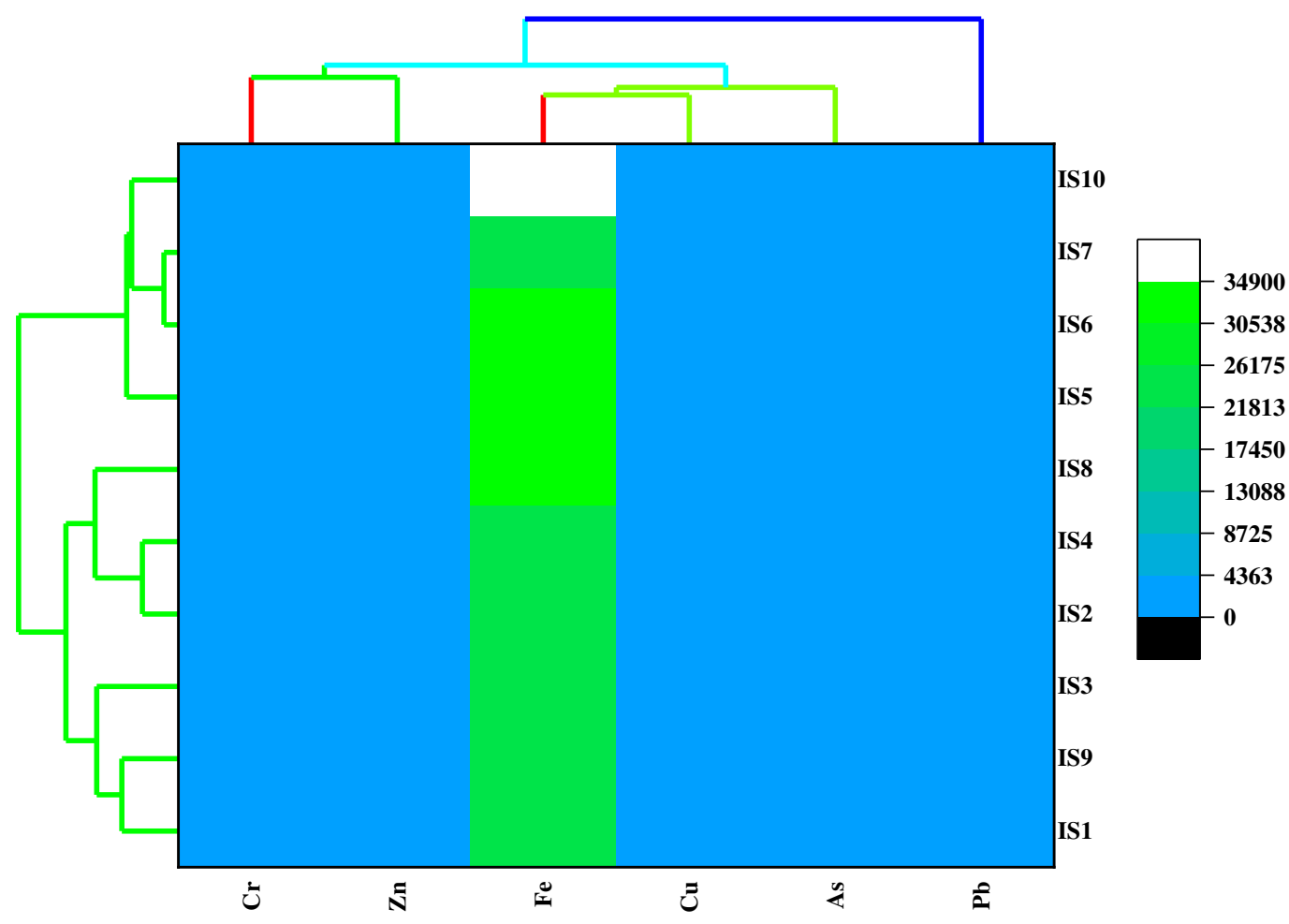

Fig.3 Hierarchical cluster diagram of sites of industrially affected soil samples (the distance reveals the degree of association between different sites based on the dissimilarity of heavy metals concentrations in soil samples) 


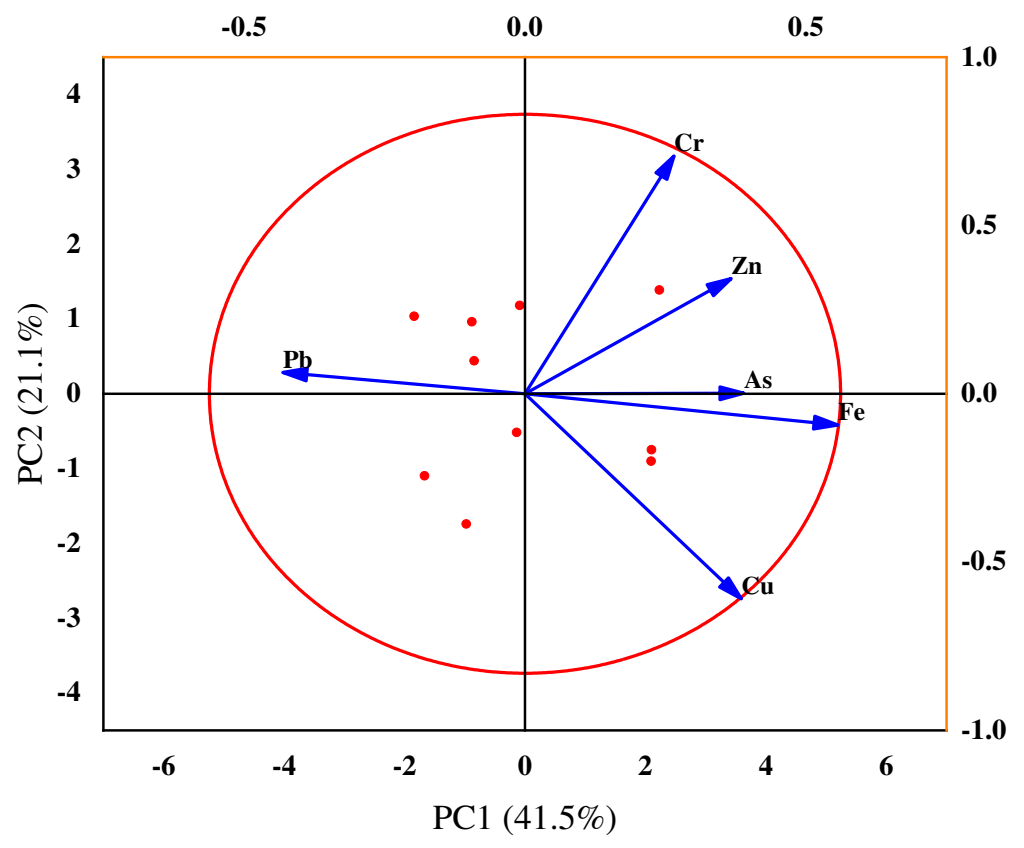

Fig.4 Heavy metals pollution source identification by PCA in the soil samples

\subsection{Heavy metal contents in vegetable samples}

Concentration of $\mathrm{HMs}(\mathrm{Fe}, \mathrm{Cr}, \mathrm{Cu}, \mathrm{Zn}, \mathrm{As}, \mathrm{Pb}$ ) in the examined vegetable samples are illustrated in Table 5. The ranges of $\mathrm{Fe}, \mathrm{Cr}, \mathrm{Cu}, \mathrm{Zn}, \mathrm{As}$ and $\mathrm{Pb}$ in vegetable sample were 368.11(radish)-45.78 (potato), 2.11 (red amaranth)0.21(potato), 19.39(spinach)-7.21(papaya), 5.35(Tomato)-2.86(radish) and 9.41(potato)-1.67(Bean) $\mathrm{mg} / \mathrm{kg}$, respectively. In a previous study, Jolly et al. (2013b) reported a different trend of metal distribution in the same vegetables of Iswardi, Bangladesh. The relative abundances of HMs in vegetable samples can be expressed as,

Fe: $\mathrm{RD}>\mathrm{RA}>\mathrm{CO}>\mathrm{CAB}>\mathrm{CF}>\mathrm{TO}>\mathrm{CAR}>\mathrm{BE}>\mathrm{BG}>\mathrm{GB}>\mathrm{PA}>\mathrm{BR}>\mathrm{PP}>\mathrm{SP}>\mathrm{PO}$;

$\mathrm{Cr}: \mathrm{RA}>\mathrm{SP}>\mathrm{CAB}>\mathrm{RD}>\mathrm{TO}>\mathrm{CO}>\mathrm{CF}>\mathrm{PP}>\mathrm{BG}>\mathrm{GB}>\mathrm{CR}=\mathrm{PO}>\mathrm{BR}=\mathrm{BE}=\mathrm{PA}$;

$\mathrm{Cu}: \mathrm{SP}>\mathrm{BG}>\mathrm{BR}>\mathrm{PO}>\mathrm{CAB}>\mathrm{CO}>\mathrm{BE}>\mathrm{CAR}>\mathrm{PP}>\mathrm{TO}>\mathrm{RA}>\mathrm{CF}>\mathrm{RD}>\mathrm{GB}>\mathrm{PA}$;

$\mathrm{Zn}: \mathrm{CO}>\mathrm{RA}>\mathrm{SP}>\mathrm{BG}>\mathrm{BR}>\mathrm{PP}>\mathrm{CAB}>\mathrm{BE}>\mathrm{RD}>\mathrm{TO}>\mathrm{PA}=\mathrm{GB}>\mathrm{CF}>\mathrm{PO}>\mathrm{CAR}$;

As: $\mathrm{TO}>\mathrm{RA}>\mathrm{SP}>\mathrm{CAB}>\mathrm{RD}>\mathrm{CO}=\mathrm{BR}=\mathrm{BE}=\mathrm{PP}=\mathrm{BG}=\mathrm{PA}=\mathrm{GB}=\mathrm{CF}=\mathrm{CAR}=\mathrm{PO}$;

$\mathrm{Pb}: \mathrm{PO}>\mathrm{BG}>\mathrm{PP}>\mathrm{BE}>\mathrm{SP}=\mathrm{CAB}=\mathrm{RA}=\mathrm{PA}=\mathrm{GB}=\mathrm{CAR}=\mathrm{TO}$.

Food and Agriculture Organization and the World Health Organization (FAO/WHO 2011) recommended the safe value for heavy metals in the vegetable samples and it was found that $\mathrm{Cr}$ and $\mathrm{Cu}$ for all the vegetables were within the legislative limit, but $\mathrm{As}$ and $\mathrm{Pb}$ found to show a value many-fold higher than the recommended value (Table 5).The high level of $\mathrm{Pb}$ and $\mathrm{As}$ in the plant species may be explained by the pollutant present in irrigation water, land texture or due to pollutants from highway traffic and the industrial establishment around the sampling site (Akinola and Njoku 2007). However, $\mathrm{Pb}$ and As are highly toxic elements, and their dietary intake via vegetables may pose both acute and chronic poisoning and can affect liver, kidney, vascular tissue, skin and the immune system adversely (Sattar et al. 2016). It is noticeable that studied HMs are distributed in vegetables in a scattered way, which may be issues of crop species variation, growth period of crops, various metal uptake capabilities of crop plant, and the part used for the edible purpose (Amin et al. 2013). In a study, Tsafe et al. (2012) observed $\mathrm{Pb}, \mathrm{Cu}$, $\mathrm{Zn}, \mathrm{Cr}, \mathrm{Cd}$ and $\mathrm{Fe}$ concentrations as 29.66, 1.13, 68.91, 16.73, 0, 97, and $195.25 \mathrm{mg} / \mathrm{kg}$ in different varieties of vegetables grown in Yargalma, Northern Nigeria and Adedokun et al. (2017) reported a lower value of $\mathrm{Cu}, \mathrm{Zn}, \mathrm{Ni}$, while a higher value of $\mathrm{Cd}, \mathrm{Pd} \mathrm{Cr}$ than the threshold value suggested by WHO/FAO in some leafy vegetables cultivated in floodplains and farmland of Lagos, Nigeria. 


\subsection{Metal Pollution Index (MPI)}

The overall heavy metal pollution in the studied vegetables is estimated by calculating MPI (Table 5). The highest MPI value was found for Papaya (14.765) and lowest for pumpkin (4.782), and both belong to fruit vegetables. However, leafy vegetables like spinach (8.120), cabbage (7.905), red amaranth (11.713) and coriander (9.588) pose a comparatively high MPI value, which was well agreement with the findings of Kashem and Singh (1999). Ahmed and Goni (2010) also reported that leafy vegetable accumulates the highest level of heavy metals, which was supported by Song et al. (2015), who believed the ability of leafy vegetables to transfer metals from soil in different parts of the plant is higher than the fruit vegetables. However, in this study, no particular trend was observed for leafy or non-leafy vegetables and hence, the variation of MPI value can be explained by variable uptake capacity of HMs by the plant, morphology and physiology, exclusion, accumulation and retention etc. Furthermore, MPI values for all the vegetables were found relatively high and can be attributed to the presence of a high level of heavy metal in the soil they have grown and suggested to avoid consumption.

\subsection{Bioaccumulation Factor (BCFs)}

Transfer of HMs from soil to plant (BCFs) depends on the soil physicochemical characteristics, types of HM accumulate and plant species (Naser et al. 2012).Heavy metal transfer from soil to crops causes many agronomic, environmental and human health problems (Rattan et al. 2005; Jolly et al. 2016; Wang et al. 2019). Many researchers have reported that many plant species can tolerate and bio-accumulate high levels of heavy metals in their tissues (Yoon et al. 2006; Kumar et al. 2015). Likewise, Lettuce (Lactuca sativa), a leafy vegetable popularly consumed by humans, accumulates high concentrations of $\mathrm{Zn}, \mathrm{Cu}, \mathrm{Cd}, \mathrm{Cr}, \mathrm{La}, \mathrm{Fe}, \mathrm{Ni}, \mathrm{Mn}, \mathrm{Pb}$, Ti, Sc and $\mathrm{V}$ (Malandrino et al. 2011). In this study, bioaccumulation factors (BCFs) of six heavy metals ( $\mathrm{Fe}, \mathrm{Cr}, \mathrm{Cu}, \mathrm{Zn}, \mathrm{As} \mathrm{Pb}$ ) from soil to edible portion of different vegetables are calculated and obtained results are computed in Table 6, which revealed BCF values varied considerably in different species of vegetables. Comparatively, a higher BCF value is found for $\mathrm{Cu}$, $\mathrm{Zn}, \mathrm{As}$ and $\mathrm{Pb}$ and hence the ranges are 0.4577-0.1702, 0.2475-0.0796, 0.1581-0.1019, 0.6874-0.1220, respectively. Sultana et al. (2015) reported that a BCF value of 0.1 is the indication of excluding elements from their tissues and when the BCF value is more than 0.2 , there is great possibility for metal contamination of vegetables by anthropogenic sources. It is mention-worthy that BCF value for As in Spinach, Cabbage, Red Amaranth, Tomato and Radish are comparatively high and can be considered as arsenic (As) extractor while, Coriander, Brinjal, Bean, Pumpkin, Bottle gourd, Cauliflower, Radish and Potato are Lead (Pb) extractor (Table 6). However, BCF values of $\mathrm{Cu}$ and $\mathrm{Zn}$ range from 0.1702-0.4577 and 0.079-0.2475 respectively but all the vegetables showed very low BCFs values for $\mathrm{Fe}$ (0.0135-0.0017) and $\mathrm{Cr}(0.0344-0.0034)$, indicating less effective translocation capacity. Nevertheless, all the studied vegetables had a BCF value <1, indicating, accumulation of heavy metals $(\mathrm{Fe}, \mathrm{Cr}, \mathrm{Cu}, \mathrm{Zn}, \mathrm{As}, \mathrm{Pb})$ by the plants' species are relatively low and less effectively translocate from soil to the edible portion of the vegetables (Hossain et al. 2020).

\subsection{Impact of HMs contaminated soil on human health}

The adverse effect of HMs contaminated soil on human health (carcinogenic and non-carcinogenic) through ingestion, inhalation and dermal contact and health risk (carcinogenic and non-carcinogenic) due to consumption of HMs contaminated vegetables for both adult and children are calculated and computed in Table 7.

\subsubsection{Soil to Human risk assessment}

In this study, health risks due to direct soil exposure are calculated considering average metal concentrations $(\mathrm{Fe}, \mathrm{Cr}$, $\mathrm{Cu}, \mathrm{Zn}, \mathrm{As}, \mathrm{Pb}$ ) of affected soil in the ten sampling site (Table 7). In case of ingestion route the highest HQ value was found for As (adult: 6.59E-02; child: 6.15E-01) and lowest for $\mathrm{Zn}$ (adult: 1.17E-04; child: 1.09E-03). In contrast, for the path inhalation, maximum HQ value was found for $\mathrm{Cr}$ (adult: 2.27E-04; child: 3.78E-04) and minimum for $\mathrm{Zn}$ (adult: 1.72E-08; child: 2.89E-08), while for dermal contact maximum $\mathrm{HQ}$ value was found for As (adult: 6.72E-03; child: 4.66E-02) and minimum for Zn (adult: 8.01E-07; child: 5.74E-06) respectively. However, the possible non-carcinogenic risk effect of $\mathrm{HMs}$ contaminated soil exposure $\left(\mathrm{HQ}_{\text {soil }}\right)$ through all three paths can be ranked in the order of $\mathrm{As}>\mathrm{Fe}>\mathrm{Cr}>\mathrm{Pb}>\mathrm{Cu}>\mathrm{Zn}$ for adult, with a similar trend for child as well, but each case, estimated value was found higher in children compared to adult (Table 7), which can be attributed by higher respiration rates per unit body weight, unawareness, unconscious hand-to-mouth activities with contaminated soils, and immature detoxification capabilities (Xiao et al. 2017) of children. Nevertheless, $\mathrm{HQ}_{\text {soil }}$ for all the calculated 
elements were found $<1$ for adult and child (Table 7), indicating low risk (Xiao et al. 2017). A similar trend was reported by Prosad et al. (2021) in the soil samples collected from Jhenidah and Kushtia district Bangladesh. However, it is noticeable that the ingestion pathway dominated over the dermal and inhalation pathway for both the population group and these results are in well agreement with the findings of Olawoyin et al. (2012); Chabukadhara et al. (2013); Hu et al. (2017); Jin et al. (2019); Kumar et al. (2019) and Rahman et al. (2019). The lifetime cancer risk (CR) for the carcinogenic metals $\mathrm{Cr}$, As, Pb (IARC 2011) have been calculated for all three paths (ingestion, inhalation, dermal contact) and the respective CR values are summarised in Table 7. Calculated CR value (Table 7) for heavy metal $\mathrm{Cr}$ was found 2.69E-07 and 9.74E-06 for adult and child respectively, which is level I contamination for adult, indicating extremely low risk and completely acceptable, whereas for child the contamination level is II, which is low in risk and suggested not to eager about the probable risk (Li et al. 2017; Orosun 2021). Furthermore, CR value for Arsenic (As) was found 2.07E-05 for adult, which is a level III contamination, indicating low-medium risk but not to mindful about the risk and CR value for As in child was found 3.00E-04, a level V contamination, indicating medium-high risk and suggested to care about the risk and to take necessary action ( $\mathrm{Li}$ et al. 2017; Orosun 2021). On the other hand, $\mathrm{CR}$ value for $\mathrm{Pb}$ is $8.68 \mathrm{E}-08$ and $8.10 \mathrm{E}-07$ for adults and children respectively, which was in Level-I category, indicating extremely low risk and lied within the acceptable range ( $\mathrm{Li}$ et al. 2017; Orosun 2021).In a study, Rahman et al. (2019) found CR value for $\mathrm{Cr}$ and As in the range of 2.97E-06 to 5.49E-06 and 5.61E-07 to $1.28 \mathrm{E}-06$ respectively in the soil dust sample of Dhaka city. A lower CR value was also reported by Kormoker et al. (2019) for child and adult for the industrially affected agricultural soil of different areas of Jinaidah and Kushtia of Bangladesh. Furthermore, Rahman et al. (2021) estimated CR value in soil samples of different schools of Dhaka, Bangladesh and found 1.41E-09 and 4.323E-09 for adults and child, respectively. However, in the present study, lifetime cancer risk (CR) is found higher in children than adults in each case, which is consistent with the finding by Proshad et al. (2021), where the calculated CR values were 9.96E-04 and 1.81E-05 for As and Pb, respectively, for the child, while those for adults were 4.16E-04 and 4.50E-06 respectively in the agricultural soil of Jhinaidhah and Kushtia district of Bangladesh.

\subsubsection{Soil to Vegetable to Human risk assessment}

In general, a variety of vegetables are consumed by different population segments throughout the year. Thus, estimation of the average intake of metal from the different varieties of vegetables is more realistic, therefore, the mean concentration of metals $(\mathrm{Fe}, \mathrm{Cr}, \mathrm{Cu}, \mathrm{Zn}, \mathrm{As}, \mathrm{Pb})$ in the 15 varieties of vegetables are considered for the calculation of health risk indices (EDI, THQ and CR) in this study (Table 7) for both the population group. The trend for estimated daily intake of metal (EDI) from consumption of vegetables are $\mathrm{Fe}(1.52 \mathrm{E}-04)>\mathrm{Cu}(1.24 \mathrm{E}-$ $05)>\mathrm{Zn}(9.80 \mathrm{E}-06)>\mathrm{Pb}(3.42 \mathrm{E}-06)>\mathrm{As}(1.70 \mathrm{E}-06)>\mathrm{Cr}(6.70 \mathrm{E}-07) \quad$ and $\quad \mathrm{Fe}(2.39 \mathrm{E}-04>\mathrm{As}(2.70 \mathrm{E}-05)>\mathrm{Cu}(1.95 \mathrm{E}-$ $05)>\mathrm{Zn}(1.40 \mathrm{E}-05)>\mathrm{Pb}(5.00 \mathrm{E}-06)>\mathrm{Cr}(1.00 \mathrm{E}-06)$ for adult and child (Table 7) respectively. The EDI of heavy metals via dietary intake of vegetables grown around $\mathrm{Pb} / \mathrm{Zn}$ smelter of southwest china among different population groups was found in the decreasing order of $\mathrm{Zn}>\mathrm{Cu}>\mathrm{Pb}>\mathrm{As}$ (Guo et al. 2019). Estimated THQ value for the studied vegetables for adult and child were found 2.17E-04, 5.00E-06, 4.1E-05, 3.00E-05, 5.68E-04, 1.71E-03 and 3.42E04, 8.00E-06, 6.50E-05, 4.80E-05, 8.93E-04, 2.69E-03, for $\mathrm{Fe}, \mathrm{Cr}, \mathrm{Cu}, \mathrm{Zn}, \mathrm{As}, \mathrm{Pb}$ respectively and all the values were below the unity $(<1)$, indicating no potential non-cancer risk from the vegetables upon consumption by both the population group. However, it is mention-worthy that, in each case, the THQ values for children are higher than the adult. This scenario is also consistent with the findings of Chen et al. (2018) and Quispe et al. (2021). In a previous study, Jolly et al. (2013b) reported to found THQ value for $\mathrm{Fe}, \mathrm{Cu}, \mathrm{Cr}, \mathrm{Pb}$, and $\mathrm{Zn}$ were $0.462,0.512$, $0.0003,0.767$ and 1.558, respectively, from the vegetable samples collected from Rooppur, Pabna, Bangladesh, which were much higher than the present value. Measured $\mathrm{CR}$ value for the carcinogenic element $\mathrm{Cr}, \mathrm{As}, \mathrm{Pb}$ was found 2.01E-09, 2.55E-08, 2.92E-08 for adult and 3.16E-09, 4.02E-08, 4.58E-08 for child respectively. All the CR values are below the threshold limit of >1E-06 and according to $\mathrm{Li}$ et al. (2017), CR values lie in the Level-I category in an extremely low-risk zone and are acceptable. Similar findings were also reported by Urrutia-Goyes et al. (2017) and Bourliva et al. (2016) in the vegetable samples of the contaminated area. In contrast, Proshad et al. (2021) reported that crops grown in Jhinadah and Kashia, Bangladesh, are polluted with $\mathrm{Cd}, \mathrm{As}$, and $\mathrm{Pb}$ and pose lifetime carcinogenic risk for both the populations.

\subsubsection{Comparison of contamination pathway}

A comparison between soil-human and soil-vegetable-human exposure pathways was made to evaluate the most vulnerable path of heavy metal for the human body and depicted in Fig. 5. The non-carcinogenic health risk accounting by direct soil exposure and vegetable consumption by calculating the Hazard Index (HI) revealed 1.19E- 
01 and 1.09E+00 for adults and children respectively (Fig.5). Lemly (1996) and USEPA (1989) categorised HI value as $<0.1,0.1<\mathrm{HI}<1, \quad 1<\mathrm{HI}<4$ and $\mathrm{HI}>4$ for negligible, low significant health effect, medium significant health effect and a very high risk respectively. However, $\mathrm{HI}$ for adult lied $0.1<\mathrm{HI}<1$, indicating low significant health effect, while for the child, HI $>1$ indicating medium significant health risk. In contrast, HI, accounting for vegetable consumption, was measured 2.57E-03 and 4.05E-03 for adults and child respectively (Fig.5), appraising HI $<1$ and revealed no risk. Similarly, total lifetime carcinogenic risk value (TCR) for soil and vegetable for both the population group were estimated (Fig. 5) and for direct soil, exposure was found 3.01 E-05 and 3.11E-04 for adults and children respectively, indicating low to medium risk for adult and medium to high risk for children, (Li et al. 2017; Orosun 2021). However, the TCR value derived for vegetable consumption was estimated 5.67E-08 and 8.91E-08 for adults and child, respectively, which lied in the Level-I category and posed extremely low risk. Thus it can be ascertained that soil to the human path is more hazardous than soil-vegetable-human path.

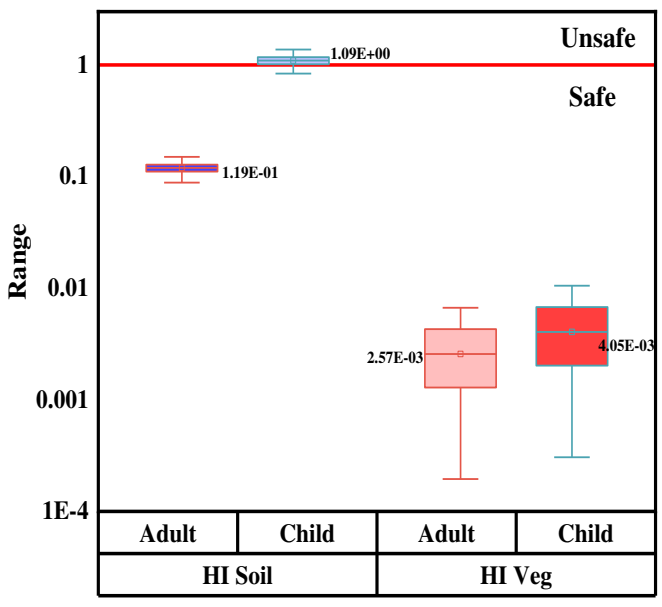

Non- Carcinogenic Risk

5(a)

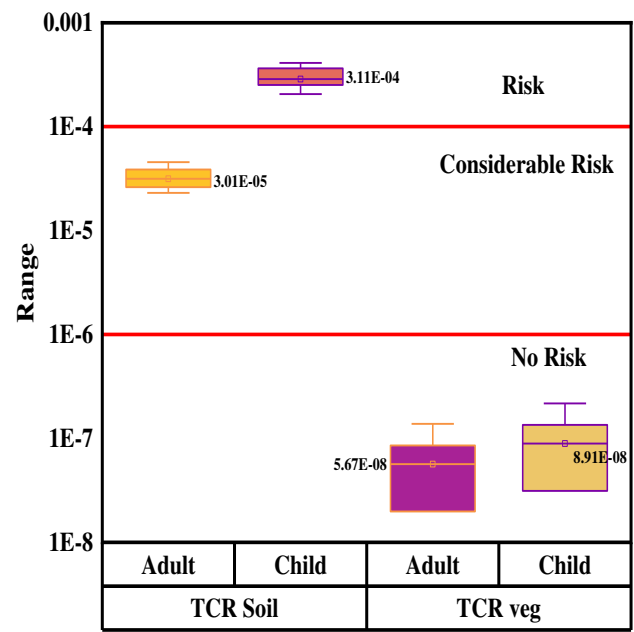

Carcinogenic Risk

5(b)

\section{Conclusion}

This study has assessed heavy metal contamination in the soil of an agricultural land adjacent to an industrial zone of Ashulia, Savar, Bangladesh and their accumulation in the cultivated vegetables on that field. The elevated level of $\mathrm{HMs}(\mathrm{Fe}, \mathrm{Cr}, \mathrm{Cu}, \mathrm{Zn}, \mathrm{As}, \mathrm{Pb})$ were found in the industrially affected soil compared to control soil and the estimated value of EF, $I_{\text {geo }}$ and CF supported this statement, moreover, calculated PLI value showed a value greater than unity for all the soil samples, indicating progressive decrease in soil quality. Multivariate statistical analysis ascertains that $\mathrm{Fe}$ and $\mathrm{Cu}$ have lithogenic sources, whereas $\mathrm{Zn}, \mathrm{Cr}$, $\mathrm{As}$, and $\mathrm{Pb}$ come from anthropogenic activities. However, the concentration of all the measured HMs in vegetables found within the legislative value suggested by FAO/WHO, 2011 except $\mathrm{As}$ and $\mathrm{Pb}$. Comparatively, a high level of MPI value was measured in all verities of vegetables and can be ranked as $\mathrm{PA}>\mathrm{BR}>\mathrm{RA}>\mathrm{BE}>\mathrm{CO}>\mathrm{RD}>\mathrm{SP}>\mathrm{CA}>\mathrm{TO}>\mathrm{PO}>\mathrm{CF}>\mathrm{GB}>\mathrm{BG}>\mathrm{CA}>\mathrm{PP}$. Calculated $\mathrm{BCF}$ value showed values lower than unity for all the elements indicating low HMs uptake capacity by the plant; however, BCF values are found near to unity by Potato (0.6874), Radish (0.5435), Coriander (0.5157), Brinjal (0.4711) and cauliflower (0.3156) for $\mathrm{Pb}$. Estimated $\mathrm{HQ}$ via direct soil exposure can be ranked as $\mathrm{HQ}_{\text {ing }}>\mathrm{HQ}_{\text {derm }}>\mathrm{HQ}_{\text {inhel }}$ regardless of age and HQ values for all the elements in the entire three pathways for adult and child were $<1$, 
indicating not to pose any health effect. Similarly, HQ via vegetable consumption was found below unity for both the population group and recommended safe. Nonetheless, HI value via direct soil exposure was measured $<1$ for adults and $>1$ for child, on the other hand, total lifetime carcinogenic health risk (TCR) for adults lied within level II (1E-05 to 1E-06) but in Level-V(1E-04 to 5E-04) for children, stipulated medium to high risk. In contrast, HI and TCR values for both the population group via dietary intake of vegetables collected from the industrially affected soil site found within the safe zone.

\section{Acknowledgements}

The authors highly acknowledged the assistance of the stuff members of the Atmospheric and Environmental Chemistry Laboratory, Chemistry Division, Atomic Energy Centre, Dhaka.

\section{Authors' contribution}

Yeasmin Nahar Jolly: Concept and design, supervision, writing, editing and final approval of the manuscript; M. Sadman Sakib, M. Ashemus Shahadat: sample collection and analysis; Shirin Akter, Jamiul Kabir, Khan M. Mamun, M. Safiur Rahman :sample analysis and data curation; M. Refat Jahan Rakib, Arafat Rahman : statistical analysis and interpretation; Bilkis Ara Begum, Rubina Rahman : supervision.

\section{Declaration}

Ethics approval and consent to participate Not applicable

Consent for publication Not applicable

Availability of data and material All data generated or analysed during this study are included in this published article

Competing interests The authors declare that they have no competing interest

Funding This research work didn't receive any grant from any governmental or non-governmental funding agencies or not-for-profit sector.

\section{References}

Adedokun AH, Njoku KL, Akinola MO, Adesuyi AA, Jolaoso AO (2017) Heavy metal content and the potential health risk assessment of some leafy vegetables cultivated in some floodplains and farmlands in Lagos, Nigeria. FUNAI J Sci Technol 3(1):30-47

Ahmad JU, Goni MA (2010) Heavy metal accumulation in water, soil and vegetables of the industrial area in Dhaka, Bangladesh. Environ Monit Assess 166:347-357

Akinola MO, Njoku KL (2007) An assessment of heavy metal pollution on the cultivated mudflat of Abule Ado floodplain Lagos state, Nigeria. J Sci Technol Environ 7(1\&2):31-39

Akter S, Islam SMA, Rahman MO, Mamun KM, Kabir MJ, Rahman MS, Begum BA, Abedin MJ, Tushar SI, Jolly YN (2019) Toxic elements accumulation in vegetables from soil collected from the vicinity of a fertilizer factory and possible health risk assessment. Op Acc J Bio Eng Bio Sci 3(2): 277-289

Alam MGM, Snow ET, Tanaka A (2003) Arsenic and heavy metal contamination of vegetables grown in Samta village, Bangladesh. Sci Total Environ 308 (1-3):83-96. doi: 10.1016/S0048- 9697(02)00651-4

Amin N, Hussain A, Alamze S, Begum S (2013) Accumulation of heavy metals in edible parts of vegetables irrigated with waste water and their daily intake to adults and children, District Mardan, Pakistan. Food Chem 136(3-4):1515-1523

Antoniadisa V, Goliaa EE, Liubic YT, Wangd SL, Sabry M, Shaheene F, Rinklebe J (2019) Soil and maize contamination by trace elements and associated health risk assessment in the industrial area of Volos, Greece. Environ Int 124:79-88

Bartolomeo DA, Poletti L, Sanchini G, Sebastiani B, Morozzi G (2004) Relationship among parameters of lake polluted sediments evaluated by multivariate statistical analysis. Chemosphere 55(10):1323e1329 
Bourliva A, Papadopoulou L, Aidona E (2016) Study of road dust magnetic phases as the main carrier of potentially harmful trace elements. Sci Total Environ 553:380-391

Brich GF, Olmos MA (2008) Sediment-bound heavy metals as indicators of human influence a biological risk in coastal water bodies. ICES J Mar Sci 65:1407-1413

Cai L, Xu Z, Ren M, Guo Q, Hu X, Hu G, Wan H, Peng P (2012) Source identification of eight hazardous heavy metals in agricultural soils of Huizhou, Guangdong Province, China. Ecotoxicol Environ Saf 78:2-8

Chabukdhara M, Nema AK (2013) Heavy metals assessment in urban soil around industrial clusters in Ghaziabad, India: probabilistic health risk approach. Ecotoxicol Environ Saf 87:57-64

Chen L, Zhou S, Shi Y, Wang C, Li B, Li Y, Wu S (2018) Heavy metals in food crops, soil and water in the Lihe river watershed of the Taihu region and their potential health risks when ingested. Sci Total Environ 615:141-149. Doi:10.1016/j.scitotenv.2017.09.230

Duan XC, Yu HH, Ye TR, Huang Y, Li J, Yuan GL, Albanese S (2020) Geo-statistical mapping and quantitative source apportionment of potentially toxic elements in top- and sub-soils: a case of suburban area in Beijing, China Ecol Indic 112:106085

Enuneku A, Omoruyi O, Tongo I, Ogbomida E, Ogbeide O, Ezemonye L (2018) Evaluating the potential health risk of heavy metal pollution in sediment and selected benithic fauna of Benin, River, Southern, Nigeria. Appl Water Sci 8:224

FAO/WHO (2011) The maximum permissible limit recommended by the Food and Agriculture Organization (FAO) and the World Health Organization (WHO). 1-18

Ferreira-Baptista L, De Miguel E (2005) Geochemistry and risk assessment of street dust in Luanda, Angola: a tropical urban environment. Atmos Environ 39:4501-4512

Gbadamosi MR, Afolabi TA, Ogunneye AL, Ogunbanjo OO, Omotola EO, Kadiri TM, Akinsipo OB, Jegede DO (2018) Distribution of radionuclides and heavy metalsin the bituminous sand deposit in Ogun State, Nigeria-a multi-dimensional pollution, health and radiological risk assessment. J Geochem Explor 190: 187-199

Guo G, Zhang D, Wang Y (2019) Probabilistic human health risk assessment of heavy metal intake via vegetable consumption around $\mathrm{Pb} / \mathrm{Zn}$ smelters in Southwest China. Int J Environ Res Public Health 16:3267. doi:10.3390/ijerph16183267

Gupta N, Yadav KK, Kumar V, Krishnan S, Kumar S, Nejad ZD, Khan MAM, Alam J (2021) Evaluating heavy metals contamination in soil and vegetables in the region of North India: levels, transfer and potential human health risk analysis. Environ Toxicol Pharmacol 82:103563. https://doi.org/10.1016/j.etap.2020.103563

Hakanson L (1980) An ecological risk index for aquatic pollution control: a sediment ecological approach. Water Res 14:975-1001

Hossain MB, Rakib MRJ, Jolly YN, Rahman M, (2020) Metals uptake and translocation in salt marsh macrophytes, Porteresia sp. from Bangladesh coastal area. Sci Total Environ 764:144637

Hu B, Jia X, Hu J, Xu D, Xia F, Li Y (2017) Assessment of heavy metal pollution and health risks in the soil-planthuman system in the Yangtze River Delta, China. Int J Environ Res Public Health 14(9):1042. doi:10.3390/ijerph14091042

IARC (2011) International agency for research on cancer. Agents Classified by the IARC Monographs. 1-102

Ihedioha JN, Ukoha PO, Ekere NR (2017) Ecological and human health risk assessment of heavy metal contamination in soil of a municipal solid waste dump in Uyo, Nigeria. Environ Geochem Health 39(3): 497-515

Islam GMR, Habib MR, Waid JL, Rahman MS, Kabir J, Akter S, Jolly YN (2017) Heavy metal contamination of freshwater prawn (Macrobrachiumrosenbergii)and prawn feed in Bangladesh: a market-based study to highlight probable health risks. Chemosphere 170:282-289

Jiang X, Lu WX, Zhao HQ, Yang QC, Yang ZP (2014) Potential ecological risk assessment and prediction of soil heavy-metal pollution around coal gangue dump. Nat Hazards Earth Syst Sci 14:1599

Jin Y, O'Connor D, Ok YS, Tsang DCW, Liu A, Hou D (2019) Assessment of sources of heavy metals in soil and dust at children's playgrounds in Beijing using GIS and multivariate statistical analysis. Environ Int 124: 320-328. doi:10.1016/j.envint.2019.01.024

Jolliffe IT, Cadima J (2016) Principal component analysis: a review and recent developments. Phil Trans R Soc Am 374: 20150202

Jolly YN, Akter S, Kabir J, Islam A (2013a) Health risk assessment of heavy metals via dietary intake of vegetables collected from an area selected for introducing a Nuclear Power Plant. Res J Phy Appl Sci 2(4):43-51 
Jolly YN, Islam A, Akbar S (2013b) Transfer of metals from soil to vegetables and possible health risk assessment. SpringerPlus 2(1):285-391. https://doi.org/10.1186/2193-1801-2-385

Jolly YN, Haque R, Islam A, Rahma, MS, Akter S, Kabir J, Munshi MK, Islam M, Khatun A, Hossain A (2016) Toxic element in rice and possible health risk assessment-Bangladesh prospect, in: Breeding and Genetic Engineering- The biology and biotechnology research, Chapter 4, iConcept press Ltd. Australia

Jolly YN. Kabir A, Akter S, Chowdhury AMS (2019) Contamination status of water, fish and vegetable samples collected from a heavy industrial are and possible health risk assessment. Adv Food Technol Nutr Sci Open J 5(2):81-91. doi: 10.17140/AFTNSOJ-5-160

Kabita-Pendias A (2011) Trace elements in soils and plants, fourth Ed. CRC Press, Boca Raton. https://doi.org/10.1016/j.moliq.2020.113025

Kashem MA, Singh BR (1999) Heavy metal contamination of soil and vegetation in the vicinity of industries in Bangladesh. Water Air Soil Pollut 115:347-361

Khan FE, Jolly YN, Islam GMR, Akhter S, Kabir J (2014) Contamination status and health risk assessment of trace elements in foodstuffs collected from the Buriganga River embankments, Dhaka, Bangladesh. Int J Food Contam 1(1):1-8. http://www.foodcontaminationjournal.com/content/1/1/1

Kormoker T, Proshad R, Islam S, Ahmed S, Chandra K, Uddin M, Rahman M (2019) Toxic metals in agricultural soils near the industrial areas of Bangladesh: ecological and human health risk assessment, Toxin Reviews. doi: 10.1080/15569543.2019.1650777

Kumar A, Sharma SK, Sharma G, Naushad M, Stadler FJ (2020) $\mathrm{CeO}_{2} / \mathrm{g}-\mathrm{C}_{3} \mathrm{~N}_{4} / \mathrm{V}_{2} \mathrm{O}_{5}$ ternary nano hetero-structures decorated with CQDs for enhanced photo reduction capabilities under different light sources: Dual Zscheme mechanism. J Alloys Compd 838:155692

Kumar V, Chopra AK, Srivastava S, Chauhan RK (2015) Accumulation of heavy metals in vegetables grown in wastewater irrigated soil in Haridwar (Uttarakhand), India. Agric Sci Res J 5:146-152

Lemly AD (1996) Evaluation of hazard quotient method for risk assessment of selenium. Ecotoxicol Environ Saf 35:156-162. doi:10.1006/eesa.1996.0095

Li F, Qiu Z, Zhang J, Liu C, Cai Y, Xiao M (2017) Spatial distribution and fuzzy health risk assessment of trace

elements in surface water from Honghu Lake. Int J Environ Res Public Health 14(9):1011. https://doi.org/10.3390/ijerph14091011

Malandrino M, Abollino O, Buoso S, Giacomino A, La-Gioia C, Mentasti E (2011) Accumulation of heavy metals from contaminated soil to plants and evaluation of soil remediation by vermiculite. Chemosphere 82:169-178. doi:10.1016/j.chemosphere.2010.10.028

Martin JM, Mebec M (1979) Elemental mass balance of materials carried by major world rivers. Mar. Chem. 7 (3):173-206

Mohammad Ali BN, Lin CY, Cleophas F, Abdullah MH, Musa B (2015) Assessment of heavy metals contamination in Mamut river soils using soil quality guidelines and geochemical indices. Environ Monit Assess 187(1):4190

Müller G (1979) Schwermetalle in den sedimenten des Rheins-Veranderungenseitt 1971. Umschan 79:778- 783

Naser HM, Sultana S, Gomes R, Noor S (2012) Heavy metal pollution of soil and vegetable grown near roadside at Gazipur. Bangladesh J Agric Res 37:9-17.

Negahban S, Mokarram M, Pourghasemi HM, Zhang H (2021) Ecological risk potential assessment of heavy metal contaminated soils in Ophiolitic formations. Environ Res 192:110305

Olawoyin R, Oyewole SA, Grayson RL (2012) Potential risk effect from elevated levels of soil heavy metals on human health in the Niger delta. Ecotoxicol Environ Saf 85:120-130

Onyele OG, Anyanwu ED (2018) Human health risk of some heavy metals in a rural spring southeastern, Nigeria. African J Environ Nat Sci Res 1(1):15-23

Orosun MM (2021) Assessment of arsenic and its associated health risks due to mining activities in parts of Northcentral Nigeria: probabilistic approach using Monte Carlo. J Hazard Mater 412:125262. https://doi.org/10.1016/j.jhazmat.2021.125262

Proshad R, Kormoker T, Saye, A, Khadka S, Idris AM (2021) Potential toxic metals (PTMs) contamination in agricultural soils and foodstuffs with associated source identification and model uncertainty. Sci Total Environ 789:147962. https://doi.org/10.1016/j.scitotenv.2021.147962

Quispe N, Zanabria D, Chavez E, Cuadros F, Carling G, Paredes B (2021) Health risk assessment of heavy metals $(\mathrm{Hg}, \mathrm{Pb}, \mathrm{Cd}, \mathrm{Cr}$ and $\mathrm{As})$ via consumption of vegetables cultured in agricultural site in Arequipa, Peru. Chem Data Collect 33:100723. https:// doi.org/10.1016/j.cdc.2021.100723

Rahman A, Jahanara I, Jolly YN (2021) Assessment of physicochemical properties of water and their seasonal variation in an urban river in Bangladesh. Water Sci Eng 14(2):139-148 
Rahman MS, Khan MDH, Jolly YN, Kabir J, Akter S, Salam A (2019) Assessing risk to human health for heavy metal contamination through street dust in the Southeast Asian Megacity: Dhaka, Bangladesh. Sci Total Environ 660:1610-1622. https://doi.org/10.1016/j.scitotenv.2018.12.425

Rahman MS, Kumar P, Ullah M, Jolly YN, Akhter S, Kabir J, Begum BA, Salam A (2021) Elemental analysis in surface soil and dust of roadside academic institutions in Dhaka city, Bangladesh and their impact on human health. Environ Chem Ecotoxicol 3: 197-208. https://doi.org/10.1016/j.enceco.2021.06.001

Rakib MRJ, Jolly YN, Enyoh CE, Khandaker MU, Hossain MB, Akther S, Alsubaie A, Almalki SA, Bradley DA (2021a) Levels and health risk assessment of heavy metals in dried fish consumed in Bangladesh. Sci Rep 11:14642. https://doi.org/10.1038/s41598-021-93989-w

Rakib MRJ, Hossain MB, Jolly YN, Akther S, Islam S (2021b) EDXRF detection of trace elements in salt marsh sediment of Bangladesh and probabilistic ecological risk assessment. Soil Sediment Contam: An Int J 1-20

Rattan R, Datta S, Chhonkar P, Suribabu K, Singh A (2005) Long-term impact of irrigation with sewage effluents on heavy metal content in soils, crops and groundwater: a case study. Agric Ecosyst Environ 109:310-322. doi:10.1016/j.agee.2005.02.025.

Rinklebe J, Antoniadis V, Shaheen SM, Rosche O, Altermann M (2019) Health risk assessment of potentially toxic elements in soils along the Central Elbe River, Germany. Environ Int126:70-88

Satter MA, Khan MM, Jabin SA, Abedin N, Islam MF, Shaha B (2016) Nutritional quality and safety aspects of wild vegetables consume in Bangladesh. Asian Pac J Trop Biomed 6(2):125-131

Selvam S, Jesuraja K, Venkatramanan S, Chung SY, Roy PD, Muthukumar P, Kumar M (2020) Imprints of pandemic lockdown on subsurface water quality in the coastal industrial city of Tuticorin, South India: a revival perspective. Sci Total Environ 738:139848

Song D, Zhuang D, Jiang D, Fu J, Wang O (2015) Integrated health risk assessment of heavy metals in Suxian Country, South China. Int J Environ Res Public Health 12:7100-7117

Sultana MS, Jolly YN, Yeasmin S, Islam A, Satter S, Tareq SM (2015) Transfer of heavy metals and radionuclide from soil to vegetables and plants in Bangladesh, in:Soil Remidiation and Plants- Prospect and Challenges, Chapter 12, Elsvier Inc., The Netherlands, pp. 331-336. http:dx.doi.org/10.1016/B978-12-799937-0-12799937-1.000127

Sun Z, Chem J (2018) Risk assessment of potential toxic elements (PTEs) pollution at a rural industrial wasteland in an abandoned metallurgy factory in North China. Int J Environ Res Public Health 15 (1):85

Sundaray SK, Nayak BB, Lin S, Bhatta D (2011) Geochemical speciation and risk assessment of heavy metals in the river estuarine sediments-a case study: Mahanadi basin, India. J Hazard Mater 186(2-3):1837-1846

Tomlinson L, Wilson G, Harris R, Jeffrey DW (1980) Problems in the assessments of heavy-metal levels in estuaries and formation of a pollution index. HelgoländerMeeresuntersuchungen 33:566-575

Toth G, Harmann T, Szatmari G, Pasztor L (2016) Maps of heavy metals in the soils of theEuropean Union and proposed priority areas for detailed assessment. Sci Total Environ 565:1054-1062

Tsafe AI, Hassan LG, Sahabi DM, Alhassan Y, Bala BM (2012) Evaluation of heavy metals uptake and risk assessment of vegetables grown in Yargalma ofNorthernigeria. J Basic Appl Sci Res 2(7):6708-6714

Ureso J, Gonzalez RE, Gracia I (1997) Trace element in bivalve mollusks Ruditapes decussates and Ruditapes Phillippinarum from Atlanta Coast of Southern Spain. Environ Int 23:291-298

Urrutia-Goyes R, Argyraki A, Orneless-Soto N (2017) Assessing lead, nickel and zinc pollution in topsoil from a historic shooting range rehabilitated into a public urban park. Int J Environ Res Public Health14 (7):698

US DOE (2004) The Risk Assessment Information System(RAIS). U.S. Department of Energy's Oak Ridge Operations Office (ORO). http://risk.lsd.ornl.gov/rap_hp.shtml

US EPA (1989) Risk assessment guidance for Superfund. Volume I: human health evaluation manual (Part A), Interim Final. 1989. U.S. Environmental Protection Agency, Office of Emergency and Remedial Response (EPA/540/1-89/002)

US EPA (1996) U.S. Environmental Protection Agency, Soil Screening Guidance: Technical Background ocument. EPA/540/R-95/128. Office of Solid Waste and Emergency Response

US EPA (2001) U.S. Environmental Protection Agency. Supplemental Guidance for Developing Soil Screening Levels for Superfund Sites. OSWER 9355.4-24. Office of Solid Waste and Emergency Response

US EPA (2008) Integrated Risk Information System. United States Environmental Protection Agency, Washington, DC, USA

USEPA (2010) Integrated Risk Information System (IRIS). United States Environmental Protection Agency, Washington, DC, USA

Wang N, Han J, Wei Y, Li G, Sun Y (2019) Potential ecological risk and health risk assessment of heavy metals and metalloid in soil around Xunyang mining areas. Sustainability11:4828. doi: 10.3390/su11184828 
Wei H, Yu H, Zhang G, Pan H, Lv C, Meng F (2018) Revealing the correlations between heavy metals and water quality with insight into the potential factors and variations through canonical correlation analysis in an upstream tributary. Ecol Indic 90:485-493

Weissmannova HD, Mihocova S, Chovanec P, Pavlovsky J (2019) Potential ecological risk and human health risk assessment of heavy metal pollution in industrial affected soils by coal mining and metallurgy in Ostrava, Czech Republic. Int J Environ Res Public Health 16(22):4495.http://doi:10.3390/ijerph16224495. doi:10.3390/ijerph16224495

Xiao R, Wang S, Li R, Wang JJ, Zhang Z (2017) Soil heavy metal contamination and health risks associated with artisanal gold mining in Tongguan, Shaanxi, China. Ecotoxicol Environ Saf 141:17-24

Yoon J, Cao X, Zhou Q, Ma LQ (2006) Accumulation of Pb, Cu and $\mathrm{Zn}$ in native plants growing on a contaminated Florida site. Sci Total Environ 368:456-464. doi:10.1016/j.scitotenv.2006.01.016

Zabir AA, Zzaman MWU, Zakir HM, Uddin MN, Islam MS (2016) Spatial dissemination of some heavy metals in soil adjacent to Bhaluka industrial area, Mymensingh, Bangladesh. Am J Appl Sci 2(6):38-47

Zhang G, Bai J, Lu QZQ, Jia J, Wen X (2016) Heavy metals in wetland soils along a wetland-forming chronosequence in the Yellow River Delta of China: levels, sources and toxic risks. Ecol Indic 69:331-339 


\section{Supplementary Files}

This is a list of supplementary files associated with this preprint. Click to download.

- Tables1and2.docx 